\title{
Interest of Rice Farmers to Apply Warehouse Receipt System in Bantul Indonesia: Theory of Planned Behavior Approach
}

\author{
Aris Slamet Widodo \\ Department of Agribusiness \\ Universitas Muhammdiyah Yogyakarta \\ Yogyakarta, Indonesia \\ armando1215sw@gmail.com
}

\author{
Mirfatus Sholichah \\ Department of Agribusiness \\ Universitas Muhammdiyah Yogyakarta \\ Yogyakarta, Indonesia \\ mirfatus@gmail.com
}

\begin{abstract}
The Warehouse Receipt System is one of the solutions of meager rice prices because it has the concept of delaying the sale of grain which aims to get a better selling price. Management performance and policy will affect farmers' interest in implementing the Warehouse Receipt System. This study aims to determine the interest of farmers in implementing the Warehouse Receipt System and to analyze the relationship between the characteristics of farmers and their interests. Sampling was conducted by way of purposive sampling method to be analyzed by the theory of planned behavior approach. The level of interest of farmers in implementing the Warehouse Receipt System in Bantul Regency is in the highest category. There is a close relationship between the characteristics of farmers and the level of interest of farmers in implementing the Warehouse Receipt System. Rice production, land area, farming experience, and rice warehouse distance are positively correlated with farmers' interest in applying the warehouse receipt system. Therefore, it is suggested that there needs to be government cooperation with farmers in managing the warehouse receipt system.
\end{abstract}

Keywords-interest, Theory of Planned Behavior, Warehouse Receipt System

\section{INTRODUCTION}

The agricultural sector is a main priority in the development of the national economy. However, as a matter of fact, until now the agricultural sector still faces various problems. The problem that often occurs among farmers is the difficulty of farmers in obtaining access to finance. To overcome this problem, the government issued a financing policy. This policy aims to ensure that agriculture becomes more productive which is consequently ensued by an increasing level of farmers' welfare.

One of the policies issued by the government is the Warehouse Receipt System (WRS). Uniquely, in this Warehouse Receipt System, farmers do not need to rush to sell their crops because farmers can store their crops first at WRS and sell them when the market price starts to stabilize. Moreover, if the harvest is high, there is often an excess supply of commodities, so that market prices are very low and have an impact on farmers' decreasing income. WRS is certainly a solution to these problems. Farmers who store their crops at WRS will receive a receipt that can be used as collateral to obtain financing from financial institutions.

With the Warehouse Receipt System, there will be opportunities for farmers to get a better selling price, by storing commodities in the warehouse first at the harvest time where prices are generally low, then selling them when prices are high. In addition, it will be more convenient for farmers to buy and sell commodities directly or through the Auction Market because they do not need to carry the commodity as a sample, but instead they only have to bring a receipt [1]. In addition, farmers can also monitor prices on the market because so far farmers feel that their price information can sometimes not be in accordance with reality, since price information is sometimes covered up by middlemen. In this way, farmers can determine the sale of grain at the best price [2].

Up to 2014, there were 92 warehouses that had implemented WRS. One warehouse receipt that has been operating is the Warehouse Receipt System in Bantul. The Warehouse Receipt System in Bantul has been operating since 2011 with commodities that can be stored, including grain and rice. The warehouse capacity is 1500 tons, but during its development the volume of new warehouse receipt transactions was 55,744 kilograms. Even though the number of commodities targeted by the government is 500,000 kilogram, in fact, in 2015 the WRS in Bantul did not make any transactions at all.

In the implementation of the warehouse receipt system in Bantul Regency, the involved stakeholders are the warehouse manager, the Trade Office, the Department of Food Agriculture, Marine and Fisheries, Agricultural Extension, and banking institutions [3]. Warehouse managers are one of the stakeholders directly related to farmers or other WRS participants and warehouses. During its development, WRS in Bantul experienced two changes to warehouse management. 2011 to 2014 was managed by KUD Tani Mulyo. While in 2015, the WRS in Bantul was not operated due to a management vacuum. However, since $23^{\text {rd }}$ of December 2016, WRS in Bantul has begun its operation again and is managed by KUD Tani Harjo.

The performance and policies set by the WRS manager at this time will affect farmers' interest in implementing WRS. This is because before the farmers plan and get interested in implementing WRS, in the first hand, farmers have to consider the amount of profits and losses they will receive, pay attention to the surrounding environment in implementing WRS, and consider their ability to implement WRS.

This is relevant to the Theory of Planned Behavior (TPB) that the interest in individual behavior will be influenced by individual judgments on the positive and negative performance of a behavior, individual perceptions 
of those who are considered to play a role, and individual beliefs in behaving. This study aims to identify the characteristics of farmers, to determine the level of interest of farmers in implementing WRS, and to analyze the relationship between the characteristics of farmers and farmers' interest in implementing WRS.

\section{METHODS}

This research was conducted in five sub-districts, consisting of Kasihan District, Sewon District, Bantul District, and Imogiri District. These locations were selected purposively because each sub-district has WRS warehouse and has received the information about WRS. The sampling was conducted by way of purposive sampling technique by involving 30 farmers who has previously received WRS information.

The data were collected by way of interviews using questionnaires to obtain primary data, while secondary data were derived from relevant parties such as the SRG manager of Bantul Regency, relevant literature from books and journals, Bantul Statistics Center, and Extension Agency Agriculture. Descriptive analysis is used to identify the characteristics of farmers. The level of interest of farmers and TPB variables were analyzed by means of arithmetic mean with the calculation of scores in table 1 .

Table 1. Range of Scores of Interest Levels and TPB's Variable in WRS Implementation

\begin{tabular}{ll}
\hline Categories & Average of Scores \\
\hline Min - Max & $1.00-4.00$ \\
Interval & 1.50 \\
Low & $1.00-2.49$ \\
High & $2.50-4.00$ \\
Range of Scores & $1-4$ \\
\hline
\end{tabular}

To determine the relationship between the characteristics of farmers with the interests of farmers, the researcher used calculations of Rs (Rank Spearman) formula. This test is used to determine the closeness of the relationship between variables $\mathrm{x}$ (farmer characteristics) and variable $y$ (interest of farmers in the application of $\mathrm{SRG).} \mathrm{The} \mathrm{calculation} \mathrm{of} \mathrm{the} \mathrm{Rs} \mathrm{formula} \mathrm{is} \mathrm{as} \mathrm{follows:}$

$$
=\frac{1-6 \Sigma D^{2}}{n\left(n^{2}-1\right)}
$$

rs: spearman rank correlation value

$\mathrm{D}$ : the difference between variable $\mathrm{x}$ and variable $\mathrm{y}$

$\mathrm{n}$ : number of samples

Table 2. Interpretation of $\mathrm{r}$ Value Correlation Analysis Results

\begin{tabular}{|c|c|}
\hline Interval value & Relationship Criteria \\
\hline $\mathrm{r}=1.00$ & Perfect relationship \\
\hline $0.90<\mathrm{r}<1.00$ & high relationship \\
\hline $0.70<\mathrm{r} \leq 0.90$ & Strong/high relationship \\
\hline $0.40<\mathrm{r} \leq 0.70$ & Relationship are meaningful \\
\hline $0.20<\mathrm{r} \leq 0.40$ & Low/definite relationship \\
\hline $0.00<\mathrm{r} \leq 0.20$ & Low/very weak relationship \\
\hline $\mathrm{r}=0.00$ & There is no correlation \\
\hline
\end{tabular}

\section{RESULTS AND DISCUSSION}

\section{A. Characteristics of Rice Farmers in Bantul Regency}

Characteristics of farmers in this study will be divided into 13 namely, education, rice production, grain reserves, farm income, land area, land ownership status, farming experience, WRS warehouse distance, frequency of socialization, barn ownership, savings ownership, loan ownership, and management group of farmers.

In general, in terms of the level of education, it is known that the education levels of farmer respondents in the warehouse receipt location are lower than the nonwarehouse receipt respondents. That is because most of the main work of non-receipt warehouse farmers is not as farmers, but as a civil servant who is still active or has retired, requiring higher education level for their occupation. This result is different from the study of [4] which shows that rice farmers in West Java only study up to elementary school so that their education levels are still relatively low and are considered successful in managing smaller farms.

The average rice production of the respondent farmers in the warehouse receipt location is higher than that of the non-warehouse receipt respondents. This is supported by the area of land owned by the respondent farmers in the warehouse receipt location that is also quite extensive. Respondent farmers in the warehouse receipt location have great potential to transact in the Warehouse Receipt System because the rice production is quite high.

Based on table 3, it is known that the average grain reserves of the respondent farmers in the warehouse receipt location are 1.574 kilograms, while the average grain reserves of the farmers respond to non-warehouse receipts are 1.517 kilograms. This data is mainly triggered by the large number of family members living in one house with the respondent farmers. The greater number of family members, the more consumption needs. Non-receipt warehouse farmers have more grain to store and transact in the Warehouse Receipt System.

Likewise, the average farmer income of farmers in the warehouse receipts location was higher, namely $\mathrm{Rp}$. 11.447.000 compared to farm income of non-warehouse receipt respondents at $\mathrm{Rp}$. 8.448.500. This indicates that the farmer respondents in the warehouse receipt location are more potential to transact in the Warehouse Receipt System because with high income the farmer respondents are motivated to improve their farming again. Different results are shown in the research of [5] which states that some respondents in Gunung Desa are included in the category of the poorest population because they have farming income of less than Rp 480.000.

The land area of the respondent of non-warehouse farmers is narrower than the land of the respondent's farm in the warehouse receipt location, where the non-receipt warehouse respondents have an average land area of 3.305 square meters, while the average land of the respondent farmers in the warehouse receipt area is 3.920. This is due to the large amount of land owned by the respondent farmers which is a division of family inheritance.

Land ownership status in the two categories of respondent farmers has the same percentage of own land 
ownership as 70\%. Therefore, farmers who respond to warehouse receipts and farmers who are not warehouse receipt respondents have equal opportunities in making decisions for their farming. One of them is by transacting in the Warehouse Receipt System.

Table 3. Average Scores and Category of Subjective Norms $(\mathrm{SN})$

\begin{tabular}{|c|c|c|c|c|c|}
\hline \multirow{2}{*}{ No } & \multirow{2}{*}{ Indicator } & \multicolumn{2}{|c|}{ Warehouse Receipt } & \multicolumn{2}{|c|}{$\begin{array}{c}\text { Non Warehouse } \\
\text { Receipt }\end{array}$} \\
\hline & & $\begin{array}{r}\text { Average } \\
\text { Scores }\end{array}$ & Category & $\begin{array}{c}\text { Average } \\
\text { Scores }\end{array}$ & Category \\
\hline 1. & $\begin{array}{l}\text { Agricultural extension } \\
\text { workers said that by } \\
\text { storing grain in the WRS } \\
\text { warehouse it had many } \\
\text { advantages so I } \\
\text { suggested that I keep the } \\
\text { grain in the WRS } \\
\text { warehouse }\end{array}$ & 2.50 & High & 2.30 & Low \\
\hline 2. & $\begin{array}{l}\text { My peasant friends } \\
\text { advised me to keep the } \\
\text { grain in the WRS } \\
\text { warehouse }\end{array}$ & 2.60 & High & 2.70 & High \\
\hline \multicolumn{2}{|c|}{ Normative Confidence } & 2.55 & High & 2.35 & Low \\
\hline 3. & $\begin{array}{l}\text { I want to follow the } \\
\text { advice of agricultural } \\
\text { extension workers to } \\
\text { store grain in the WRS } \\
\text { warehouse }\end{array}$ & 2.30 & Low & 270 & High \\
\hline 4. & $\begin{array}{l}\text { I want to do what my } \\
\text { fellow farmers friends } \\
\text { suggest storing grain in } \\
\text { the WRS warehouse }\end{array}$ & 2.20 & Low & 2.05 & Low \\
\hline \multicolumn{2}{|c|}{ Motivation Comply } & 2,25 & Low & 2,34 & Low \\
\hline \multicolumn{2}{|c|}{ SN } & 2,40 & Low & 2,35 & Low \\
\hline
\end{tabular}

Based on Table 3, it is revealed that the respondent farmers in the warehouse receipt location had longer experience in farming than the non-warehouse receipt respondents. Farmer respondents with long-standing farming experience have known many government programs to improve the welfare of farmers and have felt the benefits of these programs. Hence, when there are new government programs such as the Warehouse Receipt System, farmers are also enthusiastic about the benefits from this Warehouse Receipt System program.

The average distance that must be taken by all respondent farmers located at warehouse receipt locations is at a distance of 2.63 kilometers from the Warehouse Receipt System. This is because the WRS warehouse is located in Tirtonirmolo Village, Kasihan District. Respondent farmers in the warehouse receipt location certainly have greater potential because they can reduce transportation costs.

In terms of information about the warehouse receipt location, more people have never received such information before. This is due to the official extension agent of the Warehouse Receipt System appointed by the Bappebti serving in the BPP in Bantul Subdistrict, making it possible for Bantul District to get conduct more information dissemination. The results of this study are in line with the research of [5] which shows that the results are that as much as $80 \%$ of farmer respondents never attended counseling. The reason was that most farmers preferred working to attending counseling.

The existence of the barn by the farmer receives the same results between the farmers who have or do not have a barn at home. Farmers who already have a barn have the habit of storing their crops in the barn even though the conditions are simple and feel safer if they store them at home. Nevertheless, there is still $50 \%$ of the potential of farmers to store grain in the WRS warehouse.

As a whole, in terms of saving ownership by farmers there are $50 \%$ of respondents who have savings at the bank. Thus, some of the farmer respondents are already familiar with the procedures at the bank because it is feared that the procedures at the bank are considered complicated so that they can indirectly affect the interest of farmers to implement the Warehouse Receipt System because the WRS orientation will be accessed by the BRI's bank. By a withdraw of money, the respondent farmers in the warehouse receipt location and outside the warehouse receipt location still have the potential to store grain in WRS and use receipts as credit collateral.

Loan ownership shows that more farmers do not have KUR loans in the warehouse receipt location than that of non-warehouse receipt respondents. This indicates that the farmer respondents in the warehouse receipt location are more potential to transact in the Warehouse Receipt System and use warehouse receipts as credit collateral at BRI Bank. The results of this study are in line with [5] which states that as much as $97.14 \%$ of respondents' farmers do not have a source of credit. Even if there is one, the credit sources used are savings and loan cooperatives, not from banks.

The management of farmers is a respondent farmer who serves as a farmer group manager. All farmers in the warehouse receipts location are farmer group administrators. This indicates that the farmer respondents in the warehouse receipt location know the information related to the Warehouse Receipt System better than the nonwarehouse receipt respondent farmers so that the respondent farmers in the warehouse receipt location have a higher potential to implement the Warehouse Receipt System.

\section{B. Level of Interest of Farmers in Bantul Regency in Implementing Warehouse Receipt System (WRS)}

Interest in the framework of the Theory of Planned Behavior (TPB) is formed by three main components, namely attitude towards behavior (ATB), subjective norms (SN), and perception of behavioral control (PBC).

\section{1) Attitude Towards Behavior (ATB}

The average score of behavioral beliefs obtained from farmers in non-warehouse receipts is higher than the average score resulted by the farmer respondents in the warehouse receipt location. This means that the nonwarehouse farmer respondents are more confident that the Warehouse Receipt System will provide benefits in improving their farming. The acquisition of the average confidence evaluation score obtained by the respondent farmers in the warehouse receipt location was higher than that of the non-warehouse receipt respondents. Therefore, the attitude of the respondent farmers at the warehouse receipt location on the behavior of the Warehouse Receipt System implementation had a higher average score of 3.09 compared to the average score of the warehouse non-receipt respondents' farmers at 3.00 . 
Table 4. Average Scores and Category of Perceived Behavioral Control (PBC)

\begin{tabular}{|c|c|c|c|c|c|}
\hline \multirow{2}{*}{ No } & \multirow{2}{*}{ Indicator } & \multicolumn{2}{|c|}{$\begin{array}{c}\text { Warehouse } \\
\text { Receipt }\end{array}$} & \multicolumn{2}{|c|}{ Non Warehouse Rec } \\
\hline & & $\begin{array}{c}\text { Average } \\
\text { Score }\end{array}$ & Category & $\begin{array}{r}\text { Average } \\
\text { Scores }\end{array}$ & Category \\
\hline 1. & $\begin{array}{l}\text { The selling price of } \\
\text { grain to middlemen } \\
\text { / slaughterers is } \\
\text { very low, thus } \\
\text { encouraging me to } \\
\text { store the grain in } \\
\text { the SRG } \\
\text { warehouse. }\end{array}$ & 2.70 & High & 2.95 & High \\
\hline 2. & $\begin{array}{l}\text { It will be easy for } \\
\text { me to store the } \\
\text { grain on SRG, if the } \\
\text { warehouse location } \\
\text { is around my } \\
\text { village. }\end{array}$ & 3.70 & High & 3.30 & High \\
\hline 3. & $\begin{array}{l}\text { I will store the } \\
\text { grain in the SRG } \\
\text { warehouse if the } \\
\text { quality of my } \\
\text { harvest complies } \\
\text { the requirements. }\end{array}$ & 2.90 & High & 2.95 & High \\
\hline 4. & $\begin{array}{l}\text { If my grain quantity } \\
\text { complies the } \\
\text { requirements, I will } \\
\text { store the grain in } \\
\text { the SRG } \\
\text { warehouse. }\end{array}$ & 2.80 & High & 2.95 & High \\
\hline 5. & $\begin{array}{l}\text { I will store the } \\
\text { grain in the SRG } \\
\text { warehouse if some } \\
\text { of the } \\
\text { transportation costs } \\
\text { are borne by the } \\
\text { warehouse receipt } \\
\text { manager. }\end{array}$ & 3.70 & High & 3.40 & High \\
\hline 6. & $\begin{array}{l}\text { I will keep the grain } \\
\text { in the SRG } \\
\text { warehouse if the } \\
\text { process is easy. }\end{array}$ & 3.20 & High & 3.15 & High \\
\hline \multicolumn{2}{|c|}{ Control Beliefs } & 3.20 & High & 3.12 & High \\
\hline 7. & $\begin{array}{l}\text { The selling price of } \\
\text { grain to middlemen / } \\
\text { slaughterers is very } \\
\text { low. }\end{array}$ & 2.60 & High & 2.70 & High \\
\hline 8. & $\begin{array}{l}\text { The location of the } \\
\text { SRG warehouse is } \\
\text { around my village. }\end{array}$ & 2.80 & High & 2.35 & Low \\
\hline 9. & $\begin{array}{l}\text { The quality of grain } \\
\text { set by SRG is } \\
\text { higher than the } \\
\text { quality of my grain. }\end{array}$ & 3.20 & High & 2.90 & High \\
\hline 10. & $\begin{array}{l}\text { The minimum } \\
\text { quantity of grain } \\
\text { that can be stored in } \\
\text { SRG is more than } \\
\text { the quantity of } \\
\text { grain owned by me. }\end{array}$ & 3.00 & High & 2.85 & High \\
\hline 11. & $\begin{array}{l}\text { All transportation } \\
\text { costs are borne by } \\
\text { warehouse receipt } \\
\text { participants. }\end{array}$ & 2.60 & High & 1,90 & Low \\
\hline 12. & $\begin{array}{l}\text { The grain storage } \\
\text { process in the SRG } \\
\text { warehouse is easy. }\end{array}$ & 2.90 & High & 2.85 & High \\
\hline Stre & ght of Control Factors & 2.70 & High & 2.60 & High \\
\hline & PBC & 2.95 & High & 2.86 & High \\
\hline
\end{tabular}

\section{2) Subjective Norm $(S N)$}

Table 3 shows that the respondent farmers in the warehouse receipt location have greater confidence in the parties who encourage them to be able to transact in the Warehouse Receipt System compared to farmers who are not warehouse receipt respondents. The biggest encouragement came from fellow farmers. This is because many farmers who have never participated in the socialization of agricultural extension workers normally get information from other fellow farmers. Meanwhile, the motivation of farmer respondents to comply with what was suggested by the parties that encouraged them to store grain in the Warehouse Receipt System was higher than the farmers who are not involved in warehouse receipt respondents. When viewed as a whole, the value of subjective norms on farmer respondents in the warehouse receipt location is higher than that of non-warehouse receipt respondents. Nevertheless, the subjective norm values of the two categories of respondent farmers are in the low category.

\section{3) Perceived Behavioral Control (PBC)}

The belief of the respondent farmers who were in the warehouse receipt location for several controlling factors to transact in the Warehouse Receipt System was greater than that of the respondents who were not Warehouse Receipts. Non-warehouse receipt respondent farmers consider transportation costs to be the most important factor. This is due to the distance that must be taken by most farmers who are not respondent to warehouse receipts to be able to store grain in the SRG warehouse far enough so that they have to spend quite a lot of transportation costs. In the [6] study, it was found that different results found that the perception of costs did not become a significant obstacle because the majority of farmers received subsidies from the Tuban District Government for both transportation costs and administrative costs

Meanwhile, based on Table 4 it can be seen that the average score for the evaluation of control factors obtained higher results for the respondent farmers in the warehouse receipt location at 2.70 compared to the non-warehouse warehouse respondent farmers. In this case, the respondent farmers in the warehouse receipt location found it easier to fulfill the factors for transacting in the Warehouse Receipt System than the non-warehouse receipt respondents. So overall the farmer respondents in the warehouse receipt location have better perception of behavioral control (PBC) than non-warehouse receipt farmers.

\section{Interest in Farmers in Implementing the Warehouse \\ Receipt System}

Farmer respondents' interest in the warehouse receipt location is higher than that of the non-warehouse receipt respondents. Farmers at warehouse receipt locations tend to be interested with it if the quantity of grain obtained at harvest has met the minimum WRS requirements. This is because even though the average grain production of farmers in the warehouse receipt location has met the minimum WRS requirements, the yield is also used as 
household consumption so that the ownership of farmers' grain is only $50 \%$ of the required WRS. Whereas farmers who are not warehouse receipt respondents' reason that they are more interested in storing grain in the WRS warehouse if the buying price of the middleman is very low. Until now, non-warehouse warehouse respondent farmers consider that the purchase price of middlemen is still at a reasonable price. Even so, this program is still considered difficult to implement by farmers.

Table 5. Level of Interest of Farmers in Implementing SRG in Bantul Regency

\begin{tabular}{llcccc}
\hline No & Variable & \multicolumn{2}{c}{ Warehouse Receipt } & \multicolumn{2}{c}{$\begin{array}{c}\text { Non Warehouse } \\
\text { Receipt }\end{array}$} \\
\cline { 3 - 6 } & & $\begin{array}{c}\text { Average } \\
\text { Score }\end{array}$ & Category & $\begin{array}{c}\text { Average } \\
\text { Score }\end{array}$ & Category \\
\hline $1 . \quad$ & 3.09 & High & 3.00 & High \\
& $\begin{array}{l}\text { Attitude } \\
\text { Towards } \\
\text { Behavior } \\
\text { Subjective } \\
\text { Sorm }\end{array}$ & 2.40 & Low & 2.35 & Low \\
3. & $\begin{array}{l}\text { Perceived } \\
\text { Behavioral } \\
\text { Control }\end{array}$ & 2.95 & High & 2.86 & High \\
\hline & & & & High \\
\hline
\end{tabular}

There are many obstacles to prevent farmers from storing crops in the Warehouse Receipt System warehouse such as a narrow area of land resulting in little yield making it only sufficient for household consumption, expensive transportation costs, and the high-quality standards.

\section{Relationship between Characteristics of Farmers and}

Farmers' Interest in Implementing WRS

To find out the relationship between the characteristics of farmers and the interest of rice farmers in applying the Warehouse Receipt System, the Spearman rank correlation test was used leading to the following result:

Table 6. Relationship between Characteristics of Farmers and Rice Farmers' Interest in Implementing a Warehouse Receipt System

\begin{tabular}{|c|c|c|c|c|c|c|c|c|}
\hline Criteria & $\mathbf{A T}$ & 3 & SN & & PB & & Inter & \\
\hline $\begin{array}{l}\text { Level of } \\
\text { Education }\end{array}$ & -0.076 & LS & -0.075 & LS & -0.218 & $\mathrm{RP}$ & -0.124 & LS \\
\hline $\begin{array}{l}\text { Rice } \\
\text { Production }\end{array}$ & 0.367 & $\mathrm{RP}$ & 0.111 & LS & 0.278 & $\mathrm{RP}$ & 0.306 & $\mathrm{RP}$ \\
\hline $\begin{array}{l}\text { Grain } \\
\text { Reserves }\end{array}$ & -0.175 & LS & 0,150 & LS & -0.162 & LS & -0.126 & LS \\
\hline Farm Income & 0.248 & $\mathrm{RP}$ & -0.025 & LS & 0.306 & $\mathrm{RP}$ & -0.104 & LS \\
\hline Land Area & 0.158 & LS & 0.270 & $\mathrm{RP}$ & 0.091 & LS & 0.225 & $\mathrm{RP}$ \\
\hline $\begin{array}{l}\text { land } \\
\text { Ownership } \\
\text { Status }\end{array}$ & 0.031 & LS & -0.330 & $\mathrm{RP}$ & -0.256 & $\mathrm{RP}$ & -0.060 & LS \\
\hline $\begin{array}{l}\text { Farming } \\
\text { Experience }\end{array}$ & 0.284 & $\mathrm{RP}$ & 0.205 & $\mathrm{RP}$ & 0,107 & LS & 0.203 & $\mathrm{RP}$ \\
\hline $\begin{array}{l}\text { WRS } \\
\text { Warehouse } \\
\text { distance }\end{array}$ & 0.037 & LS & $-0,113$ & LS & 0.337 & $\mathrm{RP}$ & 0.194 & LS \\
\hline $\begin{array}{l}\text { Frequency of } \\
\text { socialization }\end{array}$ & -0.253 & $\mathrm{RP}$ & -0.785 & $\mathrm{RP}$ & -0.028 & LS & -0.253 & $\mathrm{RP}$ \\
\hline $\begin{array}{l}\text { The existence } \\
\text { of a granary }\end{array}$ & -0.237 & $\mathrm{RP}$ & 0.032 & LS & -0.120 & LS & -0.099 & LS \\
\hline $\begin{array}{l}\text { Savings } \\
\text { Ownership }\end{array}$ & -0.014 & LS & -0.090 & LS & -0.009 & LS & -0.082 & LS \\
\hline $\begin{array}{l}\text { Loan } \\
\text { Ownership }\end{array}$ & 0,182 & LS & 0,097 & LS & $-0,075$ & LS & $-0,106$ & LS \\
\hline $\begin{array}{l}\text { Management } \\
\text { of Farmer }\end{array}$ & -0.081 & LS & -0.372 & $\mathrm{RP}$ & -0.080 & LS & -0.106 & LS \\
\hline
\end{tabular}

Information:

$\mathrm{RP}=$ Low/definite relationship

$\mathrm{LS}=$ Low/very weak relationship

Education and interest are known to have a very low and negative relationship. This means that there is a tendency when farmers have the low level of education, they will have a higher interest in the Warehouse Receipt System. The results of this study are different from [7] study which revealed that the level of education has a significant relationship with the motivation of farmers in the cultivation of mendong plants.

Rice production has a low relationship with farmers' interest in implementing the Warehouse Receipt System with the direction of positive correlation. Respondent farmers whose yields are quite a lot will be more interested in transacting with the Warehouse Receipt System. In contrast to the results of the research [8] which showed the results that the amount of production in the previous planting season was not significantly related to the motivation to store crops. Farmer respondents do storage not because of a lot or least amount of production of crops in the last season, but based on willingness and need.

Grain reserves are very low in relation to farmers' interest in implementing the Warehouse Receipt System (rs $=0.126$ ) with a negative relationship direction. This means that the more rice reserves used by the respondent farmers, the farmers' interest in implementing the Warehouse Receipt System tends to be low.

The relationship between farm income and the level of interest of farmers in implementing the Warehouse Receipt System is a very low with negative correlation. Farmer respondents with high farming income will have a low interest to implement the Warehouse Receipt System in their farm because the farmer respondents already have enough income for the next farm so that they do not have to delay selling their crops in the WRS warehouse.

The level of farmers' interest has a low relationship (rs $=0.225$ ) and is positive with land area. Farmers who have a narrow area of land will affect the yields obtained. This result is supported by the research of [9] which says that farmers who have narrow land and must manage in groups are quite troublesome for farmers. As a result, farmers who have a narrow area of land tend not to be interested in implementing the Warehouse Receipt System.

Land ownership status has a negative relationship and has a very low correlation value with the level of interest of farmers. Farmers who own their own land, rent, or profitsharing systems will tend not to be interested in storing the harvest in the Warehouse Receipt System warehouse. Regardless of the role of farmers in making decisions on their farms, basically the area of land owned by farmers is not wide enough so that the yield of the crop is not much.

There is a relationship between the experiences of farming of the respondents with the level of interest of farmers, but the correlation is fairly low with the positive correlation. Farmers who have been farming for a long time have felt the benefits of government programs for the welfare of farmers, such as the Warehouse Receipt System, so that farmers are also more enthusiastic about WRS. Therefore, farmers tend to be interested in implementing the 
Warehouse Receipt System. The results of this study are in line with the results of [8] which states that farming experience is significantly related to their motivation for storing crop yields because the length of experience of the farmer in the effort to guarantee an increase in the willingness to save the harvest.

The relationship between the level of interest of farmers and WRS warehouse distance has a very low relationship ( $\mathrm{rs}=0.194)$ with a positive correlation. In general, the distance between farmers' houses close to WRS warehouses tends to be more interested in implementing WRS. This is due to the amount of transportation costs that will be incurred by farmers to transport the crops that will be stored in the WRS warehouse. [9] Research shows that the distance from farmers' fields to WRS warehouse locations has the consequence of the high cost of transportation, making it difficult for farmers to use WRS.

The frequency of information dissemination is very low and is negatively related with the interests of farmers. This means that the more frequent the information dissemination ever followed by the respondent farmers, the lower the interest of farmers to save their harvest in the Warehouse Receipt System because farmers consider there is no different materials delivered in each information dissemination. In fact, the reality is that the quantity and quality of grain have not complied with the standards.

The relationship between the existence of a granary and the level of interest of farmers is very low $(\mathrm{rs}=0.099)$ and are negatively correlated. Farmer Respondents who possess barns in their homes tend to have low interest in the application of the Warehouse Receipt System. This is because farmers already have a personal barn to store their crops even though the barn conditions are very simple. This research is supported by [10] which said that farmers in Indramayu Regency had difficulties to implement the Warehouse Receipt System. This is because farmers with large and small scale have a barn in their homes.

The level of interest of farmers with ownership of savings is insignificant $(\mathrm{rs}=0.082)$ and negatively correlated. Farmer Respondents who have savings will tend not to be interested in implementing the Warehouse Receipt System because if they have savings, they can use the savings when they have difficulty financing the next planting season.

Table 6 shows that the relationship between loan ownership and the level of interest of farmers is low (rs = 0.106) and is negatively correlated. Farmer respondents who have loans at banks and other places will tend to have low interest in delaying the sale of grain. This is because in general farmers immediately sell their crops in order to immediately repay their loans.

The correlation value of farming management is 0.106 and is negatively related. Farmers respondent as farmer group managers do not have a real relationship with interest in implementing the Warehouse Receipt System. Basically, according to farmers, the main factors to transact at WRS are the quantity and quality of grain.

\section{CONCLUSION}

The farmer respondents in Bantul Regency, mostly have completed senior high school level, have 1-3 tons of rice production, own up to 1.250 kilograms of grain reserves, have a farming income of more than Rp. 12.100.000, owned land between 500-4.125 square meters, , have farming experience of 26 years, have not received information dissemination, have a private barn, have no loans at the bank, and have not served as a farmer group manager.

The level of interest of farmers in Bantul Regency in implementing the Warehouse Receipt System in Bantul Regency is in the high category. The relationship between the characteristics of farmers and the level of interest of farmers in implementing the Warehouse Receipt System is very low. Characteristics that have a positive relationship are rice production, land area, farming experience, and WRS warehouse distance. While the characteristics that have a negative relationship are the level of education, grain reserves, farm income, land ownership status, frequency of information dissemination, the existence of barns, saving ownership, loan ownership, and farmer group management.

\section{REFERENCES}

[1] Bappeda. Outlook 2015 Sistem Resi Gudang Dan Pasar Lelang Komoditas (online). 2015.

[2] Febrian, Adi. Analisis Pendapatan Usahatani Padi Dengan Memanfaatkan Sistem Resi Gudang Studi Kasus Gapoktan Jaya Tani Indramayu. Skripsi. Institut Pertanian Bogor. Bogor. 2011.

[3] Fachruddin, A., dan Lestari Rahayu. Evaluasi Prasyarat Keberhasilan Sistem Resi Gudang di Kabupaten Bantul. AGRARIS: J. Agri. Rur. Dev. Res. Vol 3, No. 2. 2017.

[4] Tinaprilla, N, N. Kusnadi, D.B. Hakim. 2013. Analisis Efisiensi Teknis Usahatani Padi Di Jawa Barat Indonesia. J. Agri., Vol 7, No. 1. 2013.

[5] Dewi, M.M., Bekti W.U., Hanifah I. Motivasi Petani Berusahatani Padi (Kasus Di Desa Gunung Kecamatan Simo Kabupaten Boyolali). AGRISTA. Vol 4. No. 3. 2016

[6] Listiani, N., dan Bagas Haryotejo. Implementasi Sistem Resi Gudang Pada Komoditi Jagung:Studi Kasus Di Kabupaten Tuban, Provinsi Jawa Timur. Buletin Ilmiah Litbang Perdagangan, Vol 7, No. 2. 2013.

[7] Dewandini, S.K.R. Motivasi Petani Dalam Budidaya Tanaman Mendong Di Kecamatan Minggir Kabupaten Sleman. Skirpsi. Universitas Sebelas Maret. Surakarta. 2010.

[8] Kusuma, A.P., Basuki S.P., Sriyoto. Faktor Yang Berhubungan Dengan Motivasi Menyimpan Hasil Panen Padi Petani Di Kabupaten Seluma. AGRISEP, Vol 14, No. 1. 2015.

[9] Suryani, Erma, Erwidodo, Iwan S.A. Sistem Resi Gudang Di Indonesia: Antara Harapan Dan Kenyataan. Analisis Kebijakan Pertanian, Vol 12, No 1:69-86. 2014.

[10] Widiyani, M. Analisis Program Sistem Resi Gudang di Kabupaten Indramayu. Tesis. Institut Pertanian Bogor. Bogor. 2014. 